\title{
Sistem Informasi Penerimaan Mahasiswa Baru Berbasis Web Pada Institut Sains dan Teknologi Al-Kamal
}

\author{
Ika Kurniawati \\ Program Studi Sistem Informasi \\ STMIK Nusa Mandiri Jakarta \\ ika.iki@nusamandiri.ac.id
}

\begin{abstract}
Abstrak. Sistem informasi penerimaan mahasiswa baru secara manual masih banyak dilakukan oleh beberapa perguruan tinggi di Indonesia. Namun permasalahannya adalah calon mahasiswa khususnya yang berasal dari luar kota banyak yang merasa kesulitan dengan sistem manual dan tentunya membutuhkan sistem informasi yang lebih efektif dan efisien. Metode penelitian yang digunakan dalam penelitian ini adalah pengembangan sistem, yaitu merancang sistem informasi penerimaan mahasiswa baru berbasis web yang dapat diakses melalui web browser. Sistem informasi penerimaan mahasiswa baru ini dibangun dengan bahasa pemrograman PHP serta memanfaatkan database MySQL sebagai database server. Hasil dari penelitian ini adalah sistem informasi penerimaan mahasiswa baru berbasis web sudah memiliki kemampuan memberikan zkemudahan bagi calon mahasiswa baru untuk memperoleh semua informasi tentang penerimaan mahasiswa baru, melakukan proses pendaftaran dan konfirmasi pembayaran secara online.
\end{abstract}

Kata Kunci: Penerimaan Mahasiswa Baru, Web, Php, Mysql

\section{Pendahuluan}

Latar Belakang MasalahKemajuan teknologi informasi yang begitu pesat ini menuntut berbagai instansi maupun perusahaan untuk bisa mengikuti perkembangannya. Diantaranya upaya mengikuti perkembangan ini yaitu dengan memanfaatkan teknologi jaringan komputer khususnya internet. Dengan penggunaan internet ini jalannya informasi menjadi lebih mudah dan cepat sehingga suatu instansi maupun perusahaan tersebut siap bersaing dan dapat meningkatkan mutu di berbagai bidang.

Institut Sains dan Teknologi Al-Kamal (ISTA) merupakan salah satu perguruan tinggi di Jakarta yang sedang berkembang, yang selalu berusaha meningkatkan kualitas pelayanan pendidikan diantaranya pada proses penerimaan mahasiswa baru. Penerimaan mahasiswa baru merupakan suatu kegiatan yang setiap tahun diselenggarakan oleh setiap perguruan tinggi.

Pada saat ini sistem penerimaan mahasiswa baru di ISTA masih konvensional, yaitu calon mahasiswa datang langsung ke kampus ISTA kemudian mendaftarkan diri dan registrasi ulang (menyerahkan persyaratan administrasi) serta harus membayar secara tunai pada hari dan jam yang telah ditentukan oleh panitia, hal itu dirasa kurang efektif dan efisien bagi pendaftar yang berasal dari dalam maupun luar kota karena keterbatasan waktu.Selain itu pengolahan data penerimaan mahasiswa baru di kampus ISTA masih menggunakan dokumen yang berupa berkas sehingga menyebabkan pengolahan data mahasiswa baru kurang cepat, tepat, dan akurat.

\subsection{Identifikasi Permasalahan}

Berdasarkan latar belakang yang telah diterangkan diatas, maka penulis mengidentifikasi permasalahan yang ada pada Institut Sains dan Teknologi Al-Kamal (ISTA), diantaranya adalah :

a. Setiap pendaftar harus datang ke kampus ISTA yang mengakibatkan tidak efektif dan efisien bagi para pendaftar yang berasal dari luar kota.

b. Proses registrasi ulang dan pembayaran pendaftaran mahasiswa baru masih menggunakan sistem offline, yang menyebabkan terbatasnya waktu untuk calon mahasiswa yang berada diluar dan dalam kota atau yang sudah bekerja.

c. Pengolahan data penerimaan mahasiswa baru di kampus ISTA masih menggunakan dokumen yang berupa berkas dan belum memiliki penyimpanan dengan basis data yang terstruktur. Hal tersebut menyebabkan pengolahan data mahasiswa baru kurang cepat, tepat, dan akurat. 


\subsection{Perumusan Masalah}

Berdasarkan pemaparan identifikasi masalah yang ada, maka dapat dirumuskan permasalahannya sebagai berikut:

a. Bagaimana membangun sebuah sistem informasi pendaftaran, registrasi ulang, dan konfirmasi pembayaran berbasis web pada kampus ISTA?

b. Bagaimana merancang sistem informasi penerimaan mahasiswa baru dengan bahasa pemrograman PHP dan memanfaatkan database MySQL sebagai databasenya.

\subsection{Tujuan Penelitian}

Tujuan dari penulisan penelitian ini adalah merancang suatu sistem yang berfungsi untuk memberikan informasi penerimaan mahasiswa baru, melakukan pendaftaran, dan konfirmasi pembayaran online melalui web agar memudahkan calon mahasiswa yang berada dalam kota maupun luar kota serta memudahkan panitia penerimaan mahasiswa baru dalam melakukan pengolahan data.

\section{Metode Penelitian}

\subsection{Teknik Pengumpulan Data}

a. Observasi

Observasi adalah suatu metode pengumpulan data melalui pengamatan secara langsung terhadap objek yang diteliti. Dalam hal ini penulis mengadakan pengamatan secara langsung pada panitia penerimaan mahasiswa baru sehingga nantinya data yang diperoleh merupakan data yang sebenarnya.

b. Wawancara

Wawancara merupakan teknik pengumpulan data dengan melakukan tanya jawab secara lisan dengan orang-orang yang berhubungan dengan penelitian. Penulis melakukan wawancara secara langsung kepada panitia penerimaan mahasiswa baru dan pihak lainnya yang terkait.

c. Studi Pustaka

Dalam hal ini penulis mengumpulkan data yang berhubungan dengan materi melalui membaca buku buku yang terkait dan melalui internet sebagai bahan referensi.

\subsection{Model Pengembangan Sistem}

Model pengembangan sistem yang digunakan untuk penulisan skripsi ini menggunakan model waterfall, model ini juga disebut dengan classic life cycle. Metode ini membutuhkan pendekatan sistematis dan sekuensial dalam pengembangan perangkat lunak, dimulai dari tingkat sistem dan kemajuan melalui analisis, desain, coding, dan testing. Menurut Pressman dalam buku Mulyanto, tahapan tahapan waterfall sebagai berikut:

a. Analisa Kebutuhan Sistem

Tahap analisis dilakukan untuk mengumpulkan data yang dibutuhkan dalam penelitian berdasarkan teori yang telah dipelajari sebelumnya. Pada tahap ini juga bertujuan untuk memperoleh informasi mengenai harapan dari pengguna sistem atau aplikasi yang akan dikembangkan.

b. Desain

Tahap desain dilakukan untuk membuat simulasi rancangan yang siap untuk diimplementasikan, berdasarkan tahap-tahap sebelumnya. Pada tahap ini akan dibuat rancangan sistem seperti arsitektur sistem, desain ERD dan desain antar muka pengguna.

c. Pengkodean

Pada tahap pengkodean atau implementasi, dilakukan pengembangan simulasi perangkat lunak sistem berdasarkan desain sistem yang dihasilkan. Desain harus diterjemahkan dalam bentuk yang dapat dimengerti oleh mesin dengan menggunakan bahasa pemrograman yang telah ditentukan.

d. Pengujian

Setelah diimplementasikan, akan dilakukan pengujian terhadap aplikasi tersebut kepada pengguna, sehingga akan diperoleh kesesuaian hasil implementasi dengan hasil dari analisis, serta harapan dan tujuan pembuatan sistem informasi penerimaan mahasiswa baru berbasis web ini. Pada tahap ini juga akan diperoleh kelebihan dan kekurangan yang dimiliki oleh sistem ini. 


\section{Hasil dan Pembahasan}

\subsection{Analisa}

Berdasarkan observasi yang telah dilakukan di Institut Sains dan Teknologi Al-Kamal, penulis mengamati dan menganalisa proses penerimaan mahasiswa baru yang masih offline di kampus ISTA diantaranya adalah :

a. Calon mahasiswa datang ke kampus, untuk menanyakan informasi dan mengambil formulir pendaftaran. Panitia PMB memberikan formulir pendaftaran (beserta nomor formulir) dan memberitahukan persyaratan yang harus dilengkapi.

b. Calon mahasiswa mengisi formulir, memilih program studi dan melengkapi persyaratannya, kemudian menyerahkan formulir dan berkas kepada panitia PMB.

c. Panitia PMB memeriksa kembali formulir dan persyaratannya, jika sudah sesuai maka calon mahasiswa melakukan registrasi ulang sekaligus membayar biaya formulir pendaftaran dan biaya kuliah.

d. Panitia PMB memberikan bukti pembayaran pendaftaran, mahasiswa yang sudah mendapatkan bukti pembayaran pendaftaran dapat mengikuti upacara penerimaan mahasiswa baru / open house sesuai dengan waktu yang telah ditentukan.

e. Panitia PMB memberikan laporan data mahasiswa yang telah registrasi dan melakukan pembayaran kepada kepala biro kemahasiswaan.

\subsection{Desain}

Berdasarkan hasil analisa alur kerja penerimaan mahasiswa baru secara offline sebelumnya, maka dapat dirancang sistem informasi penerimaan mahasiswa baru berbasis web yang digambarkan dalam diagram berikut:

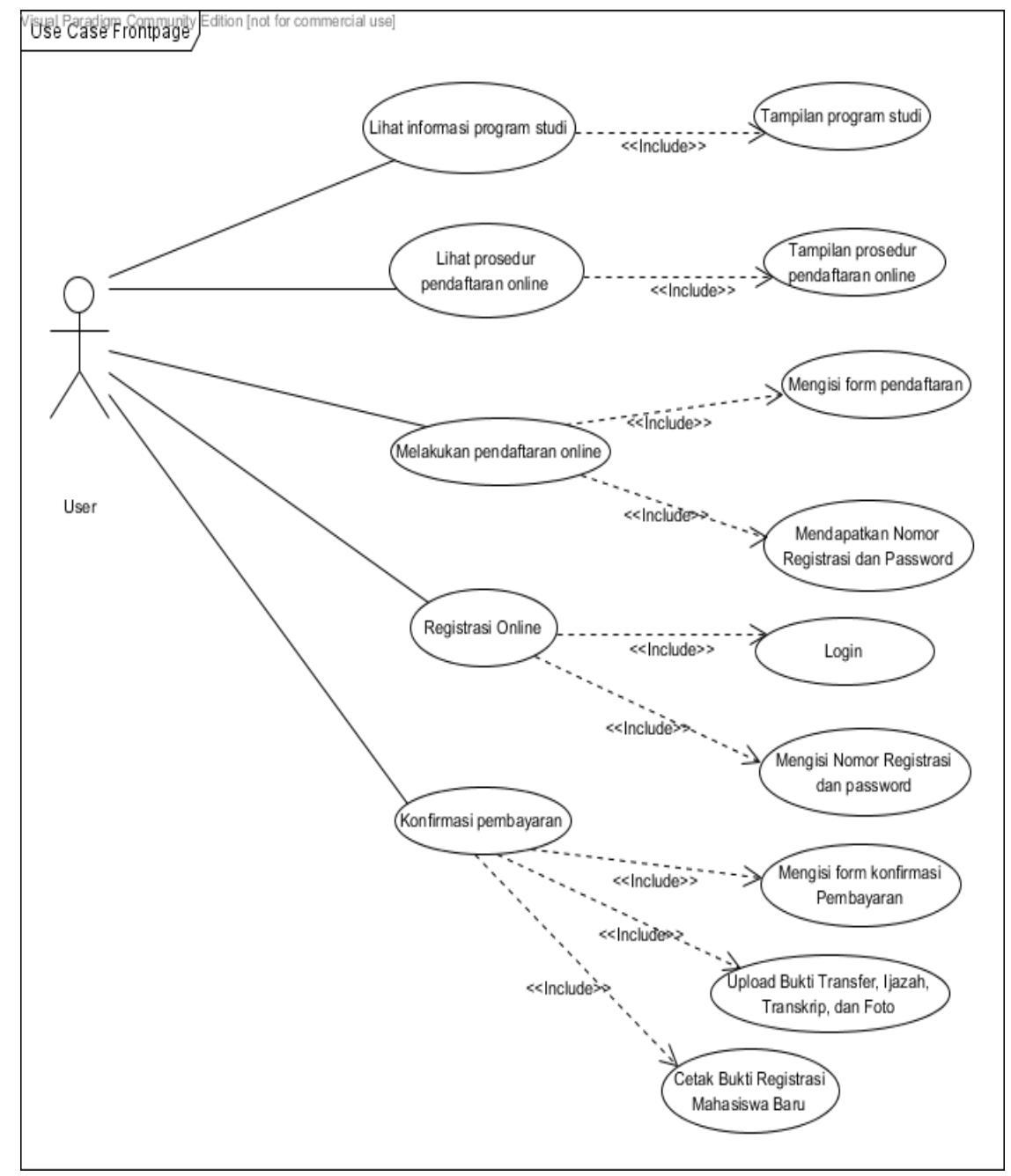

Gambar. 1. Use Case Diagram Pendaftaran Online Halaman Front Page 


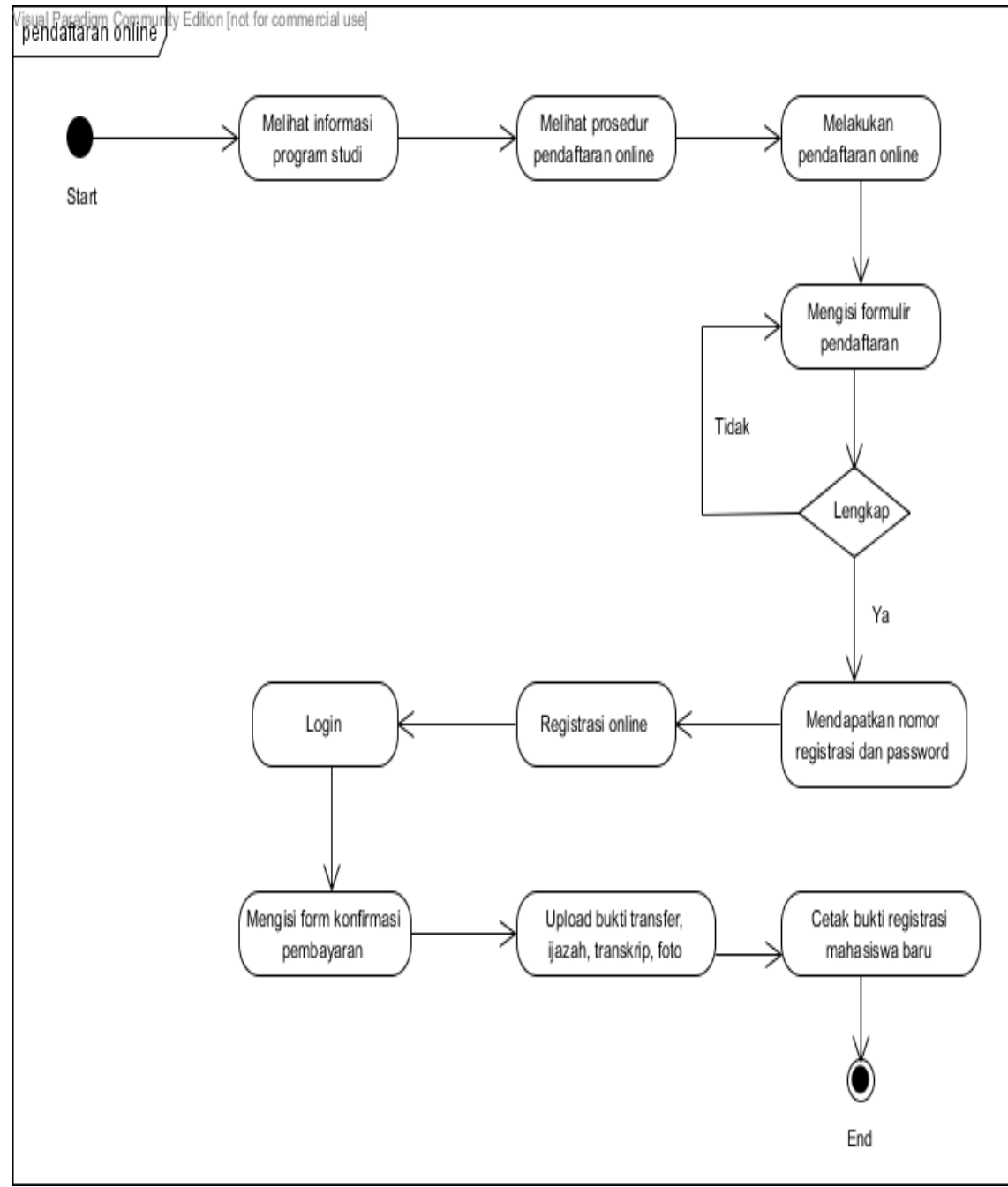

Gambar. 2. Activity Diagram Pendaftaran Online Halaman Front Page

Untuk penggambarkan hubungan antar tabel dan relasi antar tabel pada sistem penerimaan mahasiswa baru ini menggunakan Desain ERD (Entity Relationship Diagram) berikut :

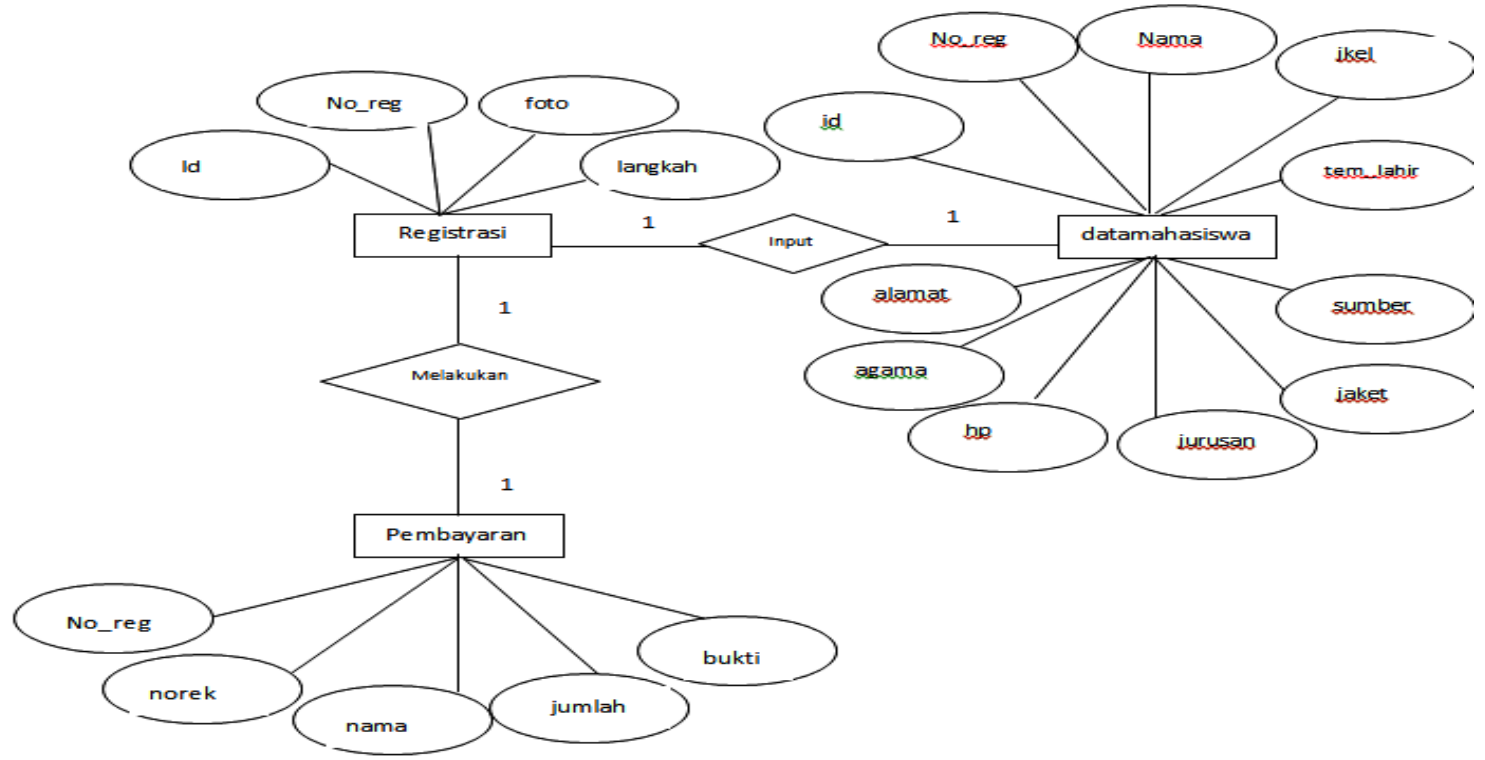

Gambar. 3. Entity Relationship Diagram Penerimaan Mahasiswa Baru 


\subsection{User Interface}

Sistem Tampilan User Interface merupakan implementasi dari draft antarmuka situs web yang penulis rancang.

1. Halaman Pendaftaran Online

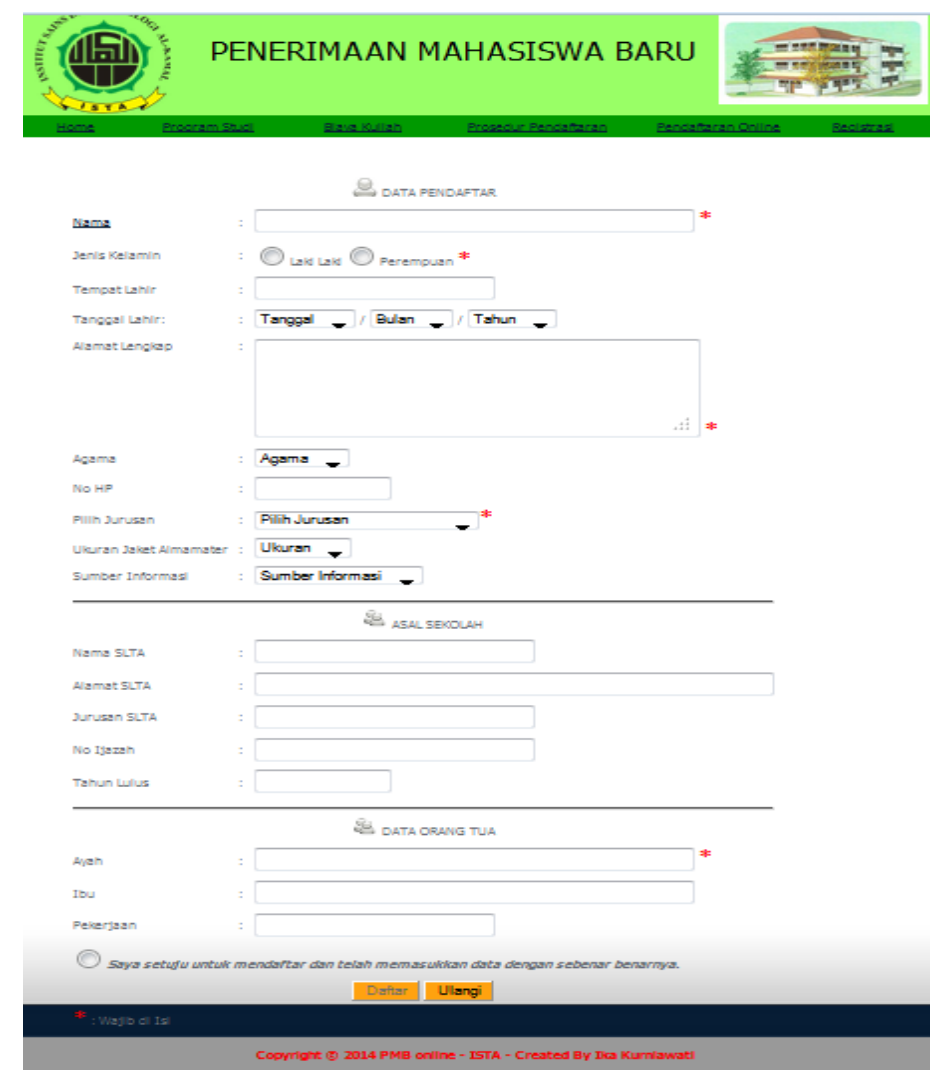

Gambar. 4. Tampilan Form Pendaftaran Online

2. Halaman Registrasi Online

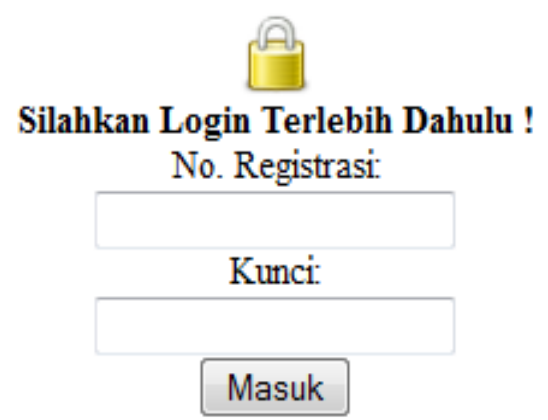

Belum Punya No. Registrasi? Silahkan Daftar Terlebih dahulu.

Copyright @ 2014 PMB online - ISTA - Created By Ika Kurniawati

Gambar. 5. Tampilan Form Login Registrasi Online 
3. Halaman Form Konfirmasi

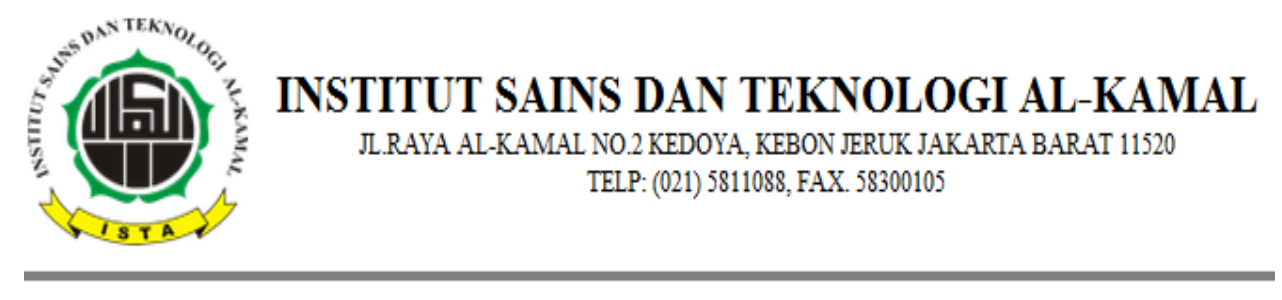

SILAHKAN ISI FORM

Biodata Siswa
No Registrasi
No Rekening
Nama
Jumlah Pembayaran
Bukti Pembayaran
Ijazah Atau SKL
Transkrip

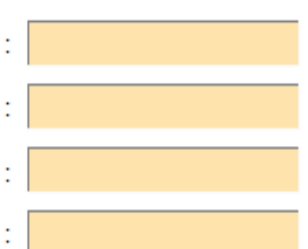

Browse_ No files selected.

Browse_ No file selected.

Browse_ No file selected.

Kirim File

Gambar. 6. Tampilan Form Registrasi Online

4. Halaman Admin Lihat Pendaftar

\begin{tabular}{|c|c|c|c|c|c|}
\hline Download Laporan PMB & Lihat Pendaftar & \multicolumn{2}{|l|}{ Lihat Konfirmasi } & \multicolumn{2}{|c|}{ Q admin to Keluar } \\
\hline \multirow{10}{*}{$\begin{array}{l}\text { Selamat Malam admin! } \\
\text { 03 Sep } 2014 \\
\text { () 23:27:09 } \\
\text { P Ganti Password }\end{array}$} & \multicolumn{5}{|l|}{4 Pendaftar } \\
\hline & \multicolumn{5}{|l|}{ Jumlah Total: 6} \\
\hline & No Registrasi & Nama Pendaftar & tem_lahir & jurusan & Menu \\
\hline & 20140002 & beno & bali & \begin{tabular}{|l|} 
Teknik \\
Informatika
\end{tabular} & $\$ Q$ \\
\hline & 20140003 & luffy & greenland & Sistem Informasi & $\sum Q$ \\
\hline & 20140007 & tri yuli & jakarta & \begin{tabular}{|l|l} 
Teknik \\
Informatika
\end{tabular} & $\sum Q$ \\
\hline & 20140008 & ika & $\mathrm{jkt}$ & $\begin{array}{l}\text { Telknik } \\
\text { Informatika }\end{array}$ & $\sum Q$ \\
\hline & 20140011 & muhsin & jakarta & Sistem Informasi & $\& Q$ \\
\hline & 20140012 & baba & jakarta & $\begin{array}{l}\text { Telknik } \\
\text { Informatika }\end{array}$ & $\sum Q$ \\
\hline & \multicolumn{5}{|c|}{ PREV|NEXT } \\
\hline
\end{tabular}

Gambar. 7. Tampilan Admin Lihat Pendaftar 


\subsection{Testing}

1. Form Pendaftaran

Tabel 1. Hasil Pengujian Black Box Testing Form Pendaftaran.

\begin{tabular}{|c|c|c|c|c|c|}
\hline No & Skenario Pengujian & Test case & $\begin{array}{l}\text { Hasil yang } \\
\text { diharapkan }\end{array}$ & $\begin{array}{l}\text { Hasil } \\
\text { Pengujian }\end{array}$ & Kesimpulan \\
\hline 1 & $\begin{array}{l}\text { Mengisi form dengan } \\
\text { lengkap, lalu mengklik } \\
\text { tombol "daftar" }\end{array}$ & $\begin{array}{l}\text { Nama: } \\
\text { Ika } \\
\text { Jenis kelamin: } \\
\text { Perempuan } \\
\text { Tempat lahir: } \\
\text { Jakarta } \\
\text { Dst } \\
\text { (lengkap) }\end{array}$ & $\begin{array}{l}\text { Sistem menyimpan } \\
\text { kemudian } \\
\text { menampilkan no } \\
\text { registrasi dan } \\
\text { password }\end{array}$ & $\begin{array}{l}\text { Sesuai } \\
\text { harapan }\end{array}$ & Valid \\
\hline 2 & $\begin{array}{l}\text { Hanya mengisi form yang } \\
\text { bertanda *, lalu mengklik } \\
\text { tombol "daftar" }\end{array}$ & $\begin{array}{l}\text { Nama: } \\
\text { Ade } \\
\text { Jenis kelamin: } \\
\text { Perempuan } \\
\text { Alamat lengkap: } \\
\text { Jakarta } \\
\text { Dst } \\
\text { (Hanya tanda *) }\end{array}$ & $\begin{array}{l}\text { Sistem menyimpan } \\
\text { kemudian } \\
\text { menampilkan no } \\
\text { registrasi dan } \\
\text { password }\end{array}$ & $\begin{array}{l}\text { Sesuai } \\
\text { Harapan }\end{array}$ & Valid \\
\hline 3 & $\begin{array}{l}\text { Mengosongkan salah satu } \\
\text { form yang bertanda *, lalu } \\
\text { mengklik tombol "daftar" }\end{array}$ & $\begin{array}{l}\text { Nama: } \\
\text { Adi } \\
\text { Jenis kelamin: } \\
\text { Tempat lahir: } \\
\text { Bandung } \\
\text { Dst }\end{array}$ & $\begin{array}{l}\text { Sistem gagal } \\
\text { menyimpan }\end{array}$ & $\begin{array}{l}\text { Sesuai } \\
\text { harapan }\end{array}$ & Valid \\
\hline
\end{tabular}

\section{Form Login Admin}

Tabel 2. Hasil Pengujian Black Box Testing Form Login Admin.

\begin{tabular}{|c|c|c|c|c|c|}
\hline No & Skenario Pengujian & Test case & $\begin{array}{l}\text { Hasil yang } \\
\text { diharapkan }\end{array}$ & $\begin{array}{l}\text { Hasil } \\
\text { Pengujian }\end{array}$ & Kesimpulan \\
\hline 1 & $\begin{array}{l}\text { Menginputkan data login } \\
\text { dengan benar, lalu mengklik } \\
\text { tombol "masuk" }\end{array}$ & $\begin{array}{l}\text { Nama : admin } \\
\text { Kunci : } 123\end{array}$ & $\begin{array}{l}\text { Sistem menerima } \\
\text { akses login dan } \\
\text { sistem } \\
\text { menampilkan form } \\
\text { admin }\end{array}$ & $\begin{array}{l}\text { Sesuai } \\
\text { harapan }\end{array}$ & Valid \\
\hline 2 & $\begin{array}{l}\text { Hanya mengisikan nama dan } \\
\text { mengkosongkan kunci, lalu } \\
\text { mengklik tombol "masuk" }\end{array}$ & $\begin{array}{l}\text { Nama : admin } \\
\text { Kunci : }\end{array}$ & $\begin{array}{l}\text { Sistem menolak } \\
\text { akses dan muncul } \\
\text { pesan "nama dan } \\
\text { kunci tidak cocok" }\end{array}$ & $\begin{array}{l}\text { Sesuai } \\
\text { Harapan }\end{array}$ & Valid \\
\hline 3 & $\begin{array}{l}\text { Menginputkan dengan } \\
\text { kondisi salah satu benar, dan } \\
\text { salah satu salah lalu } \\
\text { mengklik tombol "masuk }\end{array}$ & $\begin{array}{l}\text { Nama: } \\
\text { Admin } \\
\text { Kunci: } \\
456\end{array}$ & $\begin{array}{l}\text { Sistem menolak } \\
\text { akses dan muncul } \\
\text { pesan "nama dan } \\
\text { kunci tidak cocok". }\end{array}$ & $\begin{array}{l}\text { Sesuai } \\
\text { harapan }\end{array}$ & Valid \\
\hline
\end{tabular}




\section{Kesimpulan}

Berdasarkan penelitian yang telah dilakukan meliputi analisis, perancangan, implementasi dan testing terhadap objek penelitian yaitu Sistem Informasi Penerimaan Mahasiswa Baru Berbasis Web pada Institut Sains dan Teknologi AlKamal Jakarta, didapati bahwa sistem informasi penerimaan mahasiswa baru berbasis web ini memberikan kemudahan kepada calon mahasiswa dalam mengakses informasi dan melakukan pendaftaran, registrasi, dan konfirmasi pembayaran secara online. Kegiatan penerimaan mahasiswa baru di Institut Sains dan Teknologi Al-Kamal Jakarta menjadi lebih sederhana yakni proses pendaftaran dari yang sebelumnya calon mahasiswa harus melakukan proses pendaftaran melalui tiga tahap bagian administrasi dengan adanya sistem informasi penerimaan mahasiswa baru

\section{Referensi}

[1] Anhar. 2010. Panduan Menguasai PHP \& MySQL Secara Otodidak. Jakarta: Media Kita.

[2] Febrian, Jack. 2008. Menggunakan Internet. Bandung: Informatika.

[3] Hidayati, Anita. 2013. Perancangan dan Pembuatan Aplikasi Pendaftaran Mahasiswa Baru. Surabaya. ISSN : 1693 4024 : Jurnal Eltek, Volume 11 Nomor 02, Oktober 2013,67-78.

[4] Irwan. 2011. Panduan Berinternet Untuk Orang Awam. Palembang: Maxikom.

[5] Kadir, Abdul. 2008. Dasar Pemrograman Web Dinamis Menggunakan PHP (Revisi). Yogyakarta: Andi Offset.

[6] Ladjamudin, Al-Bahra Bin. 2005. Analisis dan Desain Sistem Informasi. Yogyakarta: Graha Ilmu.

[7] Mulyanto, Agus. 2009. "Sistem Informasi Konsep \& Aplikasi”. Pustaka Pelajar, Yogyakarta.

[8] Nurhayani. 2013. Sistem Informasi Pendaftaran Mahasiswa Baru (PMB) di AMIK Sigma Palembang. ISSN : 2303 5786 : Jurnal Sigmata, Volume 2 Nomor 1, Oktober 2013, 52-61.

[9] S, Rosa A. M. Shalahuddin. 2013. Rekayasa Perangkat Lunak Terstruktur dan Berbasis Objek. Bandung. Informatika.

[10] Shalahuddin, M., dan Rosa A.S. 2008. Java di Web. Bandung: Informatika.

[11] Sutabri, Tata. 2005. Sistem Informasi Manajemen. Yogyakarta: Andi Offset.

[12] Wijaya, dkk. 2010. Sistem Informasi Penerimaan Mahasiswa Baru Berbasis Web dan Wap. Yogyakarta. ISSN : 1978 0176 : Seminar Nasional VI, November 2010, $395-404$ 